\title{
DIRECTIONS OF CHANGE IN THE POLISH TWO-TIER BOARD MODEL
}

\author{
Leszek Bohdanowicz. \\ Department of Business Management, \\ Faculty of Management, University of Lodz, Poland, \\ e-mail address: lbohdan@uni.lodz.pl
}

\begin{abstract}
Purpose: This paper is devoted to the effectiveness of corporate boards. Its aim is to present the board models found in European companies and to propose changes that would lead to better performance of Polish corporate boards.

Approach: The article presents an analysis of European corporate board models, as well as their advantages and disadvantages. Based on this analysis, the author pointed out possible directions of change in the Polish two-tier board model.

Implications: The author suggests that the introduction of an optional model, whereby the shareholders can choose between the one-tier board model (board of directors) and the two-tier board model (supervisory board and management board), would enable better use of the social and intellectual capital present in the corporate boards of Polish companies.
\end{abstract}

Keywords: corporate governance, corporate boards, board-level employee representatives

Paper type: Viewpoint

\section{Introduction}

According to the concept of positive organizational potential, organizations strive to foster positive qualities and emotions, including trust, cooperation, and satisfaction (Haffer and Glińska-Neweś, 2013; Rozkwitalska, 2012; Stankiewicz, 2010). This positive potential is meant to help organizations achieve superior performance. In the case of companies, the focus is on above-average financial performance, which cannot be attained without creating appropriate operating conditions at the very top, that is, conditions for the effective implementation of management and supervisory functions by corporate governing bodies (supervisory and management boards).

The creation of adequate conditions for the functioning of corporate boards has been widely discussed both in the Polish literature (Bohdanowicz, 2009; Jeżak, 2010; Rudolf et al., 2002) and the world literature (Demb and Neubauer, 
DIRECTIONS

OF

CHANGE

Leszek Bohdanowicz

1992; Nadler et al., 2006; Tricker, 2009), especially since the time boards came under strong criticism for their inability to predict and prevent executive abuse of power in companies such as Enron, WorldCom, Bremer Vulkan, Banesto, Parmalat, and Lehman Brothers. In Poland, the passivity of supervisory boards and their small impact on companies' strategies has often been emphasized (Jeżak, 2009). This is largely due to their legal position and the functions granted to them under the Commercial Companies Code, as their responsibilities are primarily of oversight nature. Because of that, the potential of board members is not utilized and companies often waste the social and intellectual capital available to them at this level.

This paper presents a viewpoint, and is part of a broader research project financed from governmental funds allocated to education in 2011-2014. The paper is devoted to the effectiveness of corporate boards, with the objective being to discuss their existing models in Europe and propose changes that would lead to better performance of corporate boards in Poland. The paper is divided into three parts. The first part presents European corporate board models and compares the advantages and disadvantages of the one-tier and two-tier models. The second part discusses the notion that the two-tier model fosters cooperation between the owners of capital and employees, and gives a brief overview of European legal solutions concerning employee representation on company boards. The third part offers some suggestions as to changes to the Polish board model. The study ends with a summary and conclusions.

\section{Corporate board models in Europe}

There are two corporate board models - the one-tier model and the two-tier model (Table 1). In the one-tier model, the company is run by a board of directors consisting of both outside directors (US), or non-executive directors (UK), and non-executive directors (UK), or inside directors (US). While the outside directors are primarily responsible for supervising the company, the inside directors are top managers dealing with the day-to-day businesses of the company. In contrast, in the two-tier model there are two bodies: the supervisory board composed of outside directors and the management board consisting of inside directors. The one-tier model was first used in the East India Company founded on December 31, 1600 in the United Kingdom. Today, this model is present in Europe in Belgium, Greece, Spain, Ireland, Sweden, the United Kingdom, Cyprus, and Malta.

The two-tier model derives from the tradition of $17_{\text {th }}$ century Dutch companies, as in 1623 it was adopted by the world's first public company i.e. the Vereenigde Oost-Indische Compagnie (the Dutch United East India Company) established in 1602, which was a symbol of the Dutch maritime trading power. The functioning and development of the two-tier model was strengthened by subsequent amendments to the German company law in the 19th and 20th centuries 
(Cadbury, 2002; Morck and Steier, 2005; Pawlak, 1996; van Bekkum et al., 2010). The two-tier model has been adopted in Austria, the Czech Republic, Denmark, Estonia, Germany, Poland, and Slovakia.

In many countries, shareholders can choose a board model; this is the case, e.g., in Bulgaria, Finland, France, the Netherlands, Luxembourg, Portugal, Romania, Slovenia, Italy, Latvia, Lithuania, and Hungary (The European Commission, 2009). Organization of statutory bodies in European countries is presented in Table 1.

There also exist some hybrid solutions. For example, in Lithuania, in accordance with the Lithuanian Civil Code, companies are not obliged to appoint any board. If, however, they choose to create such a body, they have three options. The shareholders may appoint a supervisory board only, a management board only, or use the two-tier system i.e. the company can establish both a supervisory board and a management board (The European Commission, 2009). Denmark has embraced the two-tier model, but, unlike in the other countries with the same board organization, the managers can also be members of the supervisory board and may take up to $50 \%$ of the seats in this body. Therefore, Rose (2005) has called the Danish model a semi-two-tier model. At the same time, to strengthen the supervisory function of the board, in the Danish public companies the same person cannot act as the chairman of the supervisory board and the president of the management board.

\begin{tabular}{ll}
\hline Country & Organization of statutory bodies \\
\hline Austria & Two-tier \\
\hline Belgium & One-tier \\
\hline Bulgaria & Optional - one-tier / two-tier \\
\hline Cyprus & One-tier \\
\hline Czech Republic & Two-tier \\
\hline Denmark & Two-tier \\
\hline Estonia & Two-tier \\
\hline Finland & Optional - one-tier / two-tier \\
\hline France & Optional - one-tier / two-tier \\
\hline Greece & One-tier \\
\hline Spain & One-tier \\
\hline Netherlands & Optional - one-tier / two-tier \\
\hline Ireland & One-tier \\
\hline Lithuania & Optional - one-tier / two-tier \\
\hline
\end{tabular}

Table 1.

Organization of corporate boards in

Europe

Source: based on The European Commission (2009), Study on Monitoring and Enforcement Practices in Corporate Governance in the Member States. 


\begin{tabular}{|c|c|c|}
\hline \multirow{3}{*}{$\begin{array}{l}\text { DIRECTIONS } \\
\text { OF } \\
\text { CHANGE }\end{array}$} & \multicolumn{2}{|c|}{ 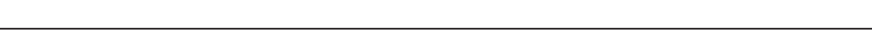 } \\
\hline & Country & Organization of statutory bodies \\
\hline & Luxembourg & Optional - one-tier / two-tier \\
\hline \multirow[t]{10}{*}{ Leszek Bohdanowicz } & Latvia & Optional - one-tier / two-tier \\
\hline & Malta & One-tier \\
\hline & Germany & Two-tier \\
\hline & Poland & Two-tier \\
\hline & Portugal & Optional - one-tier / two-tier \\
\hline & Romania & Optional - one-tier / two-tier \\
\hline & Slovakia & Two-tier \\
\hline & Slovenia & Optional - one-tier / two-tier \\
\hline & Sweden & One-tier \\
\hline & Hungary & Optional - one-tier / two-tier \\
\hline \multirow{2}{*}{$\begin{array}{l}\text { Table } 1 . \\
\text { contiuned }\end{array}$} & Italy & Optional - one-tier / two-tier \\
\hline & Great Britain & One-tier \\
\hline
\end{tabular}

The difference between the one-tier and two-tier models is not just technical. Each model has its advantages and disadvantages, which have been presented by, e.g., Aste (1999), Cadbury (2002), Jeżak (2010), Jungman (2006), MilletReyes and Zhao (2010), Spisto (2005), and Tricker (2009). These advantages and disadvantages can be discussed in the context of independence of board members and their conflict of interest, the flow of information, and flexibility.

In the two-tier model, members of the supervisory board are, at least theoretically, independent of the management board. They sit on a separate body whose tasks are clearly defined by the law. In a one-tier model, the inside and outside directors are still members of one body, which often constrains their independence due to loyalty to their colleagues. Because of this problem, independence of board members has been the subject of many studies and has also been incorporated in codes of best practice for corporate governance. In fact, a lack of independence of board members has been recognized as one of the major causes of difficulties preventing detection of managerial abuse of power and resulting in the bankruptcy of many companies.

The main advantage of the two-tier model, i.e., the independence of supervisory board members, does not, however, automatically lead to effective supervision, and supervisory bodies in this model are seen as passive and reactive. This is caused by an inappropriate flow of company information to the supervisory board. Supervisory boards work with the data supplied by the management board and practically controlled by the president of that board. Such data are often incomplete, making effective corporate supervision impossible. This problem is much less severe in the one-tier model as the inside and outside members of the 
board of directors use the same documents and bear the same responsibility for the business of the company. Of course, because of the time they devote to the affairs of the company, the inside members have privileged access to information, but the disproportion between the amount of company information available to them and to the outside directors is much smaller than that between members of the management board and members of the supervisory board.

Another advantage of the one-tier model is its flexibility. Boards of directors may have different compositions and focus on different functions. In a subsidiary of a holding company or in a family company, the board of directors may be dominated by inside members and focus on managerial functions. Public companies with a dispersed ownership structure may have a greater proportion of outside members, so the board could better fulfil supervisory functions. The very composition of the board of directors provides owners with a chance to adjust the body to the company's needs and challenges. The two-tier model is different. The supervisory board has clearly defined tasks and composition. The supervisory board always consists only of outside members and must be appointed, regardless of whether it is effective or not and whether is tasks overlap with other mechanisms of managerial supervision or not. The latter may be the case in holdings, where ownership supervision offices are often created.

\section{Corporate board models and employee representation on boards}

The two-tier model is sometimes associated with employee participation in company supervision. For example, while comparing the two types of board models (the American one-tier model and the German two-tier model), Mayer (1995) observed that the American model reflects the view that a limited liability company cannot be separated from the shareholders and that acting in the interest of the company automatically means acting in the interest of the shareholders. However, the German model of the board is based on the assumption that the company goes beyond the interests of the shareholders, and the board's task is to overcome differences in the interests of the main stakeholders. In fact, the possibility of introduction of the two-tier model was also discussed in the UK, at the time when the Committee of Inquiry led by Alan Bullock was working on its report (The Report of the Committee of Inquiry on Industrial Democracy). The report raised the issue of employee representation on boards. At that time it was decided that in the two-tier model supervisory boards are passive and react to the situation of the company rather than take part in shaping its policies and strategies. The authors of the report themselves favored a model similar to the Danish one i.e. a semi-two-tier model. Eventually, it was concluded that workers' democracy could be implemented through a more active one-tier model (Davis, 1978).

Employee representation on supervisory boards in the two-tier model is quite common, although not in every country that has adopted such a model 
DIRECTIONS

$\mathrm{OF}$

CHANGE

Leszek Bohdanowicz

Table 2.

Employee

representatives in

various corporate

board models in

Europe

Source: based

on The European

Commission (2009),

Study on Monitoring

and Enforcement

Practices in

Corporate

Governance in the

Member States.
(Rudolf, 2008). Legal solutions ensuring worker representation are found in Germany, Austria, the Czech Republic, and Slovakia. In contrast, such an option is almost absent in Estonia and Poland, where only a few companies apply it. In Poland, employee representation on supervisory boards is not provided for in the Commercial Companies Code, and their presence results mainly from the provisions of the Act on Commercialization and Privatization of State Enterprises. Such a solution is also nonexistent in Denmark, where a semi-two-tier model is present. In turn, employee representation on boards is guaranteed by the law in some countries with an optional board model (Finland, France, Slovenia, and Hungary) and one-tier model (Sweden). These solutions are presented in Table 2. In Slovenia, employees can also appoint their representative not only to the supervisory board, but also to the management board, and, similarly they can appoint an inside member if the company has adopted a one-tier model (The European Commission, 2009).

\begin{tabular}{ll}
\hline Country & Employee representation on boards \\
\hline Austria & $\begin{array}{l}\text { Employees have the right to delegate one representative to the board for every two } \\
\text { shareholder representatives }\end{array}$ \\
\hline Czech & $\begin{array}{l}\text { In companies with more than } 50 \text { employees, one-third of the board are workers' } \\
\text { representatives }\end{array}$ \\
\hline Finland & $\begin{array}{l}\text { The law allows employee representatives on the boards of companies that employ } \\
\text { more than } 150 \text { employees. }\end{array}$ \\
\hline France & $\begin{array}{l}\text { Employees may be appointed to the board, but their number should not exceed } \\
\text { one-third of all members. Employees should be represented on the board if em- } \\
\text { ployee ownership amounts to } 3 \text { percent or more. }\end{array}$ \\
\hline Germany & $\begin{array}{l}\text { Under the principle of co-determination, employee representatives account for half } \\
\text { of the board in large companies (with more than 2000 employees) }\end{array}$ \\
\hline Slovakia & $\begin{array}{l}\text { In companies with more than } 50 \text { employees, employee representatives account for } \\
\text { one-third of the board }\end{array}$ \\
\hline \multirow{2}{*}{ Slovenia } & $\begin{array}{l}\text { If a company has a single-tier model, employees have the right to appoint at least } \\
\text { one member of the board of directors. In turn, in companies with a two-tier model, } \\
\text { representatives may account for one-third to one-half of the members of the super- } \\
\text { visory board. }\end{array}$ \\
\hline Sweden & $\begin{array}{l}\text { Employees have the right to elect up to three members of the board. In public } \\
\text { companies, however, their number cannot be greater than the number of members } \\
\text { appointed by the general meeting of shareholders. }\end{array}$ \\
\hline Hungary & $\begin{array}{l}\text { If the number of full-time employees in the company exceeds 200, they have the } \\
\text { right to participate in the supervision of the company. The number of employee } \\
\text { representatives on the supervisory board amounts to one-third of all its members. } \\
\text { Other solutions can be arranged by an agreement between the works council and } \\
\text { the management of the company. }\end{array}$ \\
\hline
\end{tabular}


The establishment of mandatory employee representation on the supervisory board does not seem possible in Polish companies. Such a discussion in Poland does not really exist, and the issue has been raised in only a few studies (Rudolf, 2008). While it is understandable that investors are not interested in it, interestingly, neither are the trade unions, which was emphasized by Rudolf. Therefore, if supervisory boards in Poland do not create favorable conditions for cooperation between the owners and employees, one should consider changes to the functioning of corporate boards in Poland that would improve the use of their potential and adapt these bodies to the needs of various types of companies. In other words, it would be worthwhile to consider the introduction of more flexible legal solutions for the functioning of corporate boards.

\section{Institutional changes in the Polish corporate board model}

As can be seen from an overall analysis of board models in the European Union, there is no single model that would be universally acceptable and considered to be superior. Many countries have firmly established solutions. However, one can see some trends that can serve as guidelines for Poland. In many countries companies can now choose between the one-tier and the two-tier model. In recent years, such solutions have been adopted, e.g. in Slovenia (2006) and the Netherlands (2012) (Spencer Stuart, 2013; The European Commission, 2009).

The adoption of the one-tier model in Poland has been suggested in some studies (see, e.g., Jeżak, 2010), but without much success. The introduction of such a solution, especially given the fact there is no employee representation on supervisory boards, would allow companies to adapt the structure of the boards to meet their needs. One should not, however, discard the two-tier model, but rather allow the owners of companies to choose a model, as it is practiced in many countries (as indicated above). The owners should define their selected governance model in the company articles of association. The two-tier model may be attractive to some shareholders and some may have grown strongly accustomed to it. Foreign investors from countries where such a model exists may be eager to use it, as observed by, e.g., Aste (1999).

The introduction of the optional board model in the Polish legislation would make company boards more flexible. In the one-tier model, a board composed of both inside and outside directors can be adjusted to the challenges facing the company, which was emphasized by, e.g., Garratt (2003) and Tricker (2009). Depending on which type of members prevail on a board of directors, it may focus on different functions. In smaller private companies and family companies, boards of directors may consist only of inside members. This kind of board composition is also often seen in subsidiaries of holding companies, and such boards are often termed "executive boards." In public companies, boards can be either non-executive or unitary. In the first case, it is the inside members who 
DIRECTIONS

OF

CHANGE

Leszek Bohdanowicz

Table 3. The results of survey on changes in the Polish board model

Source: author's calculations based on data obtained from survey. outnumber the outside members. In the second case, their numbers are similar or the inside members are in the majority. Boards of different composition may place greater emphasis on defining the strategic direction of the company, managing the company, or supervising the managers.

\section{The results of the questionnaire research on changes in the Polish board model}

Opinions among the members of the Polish supervisory boards on changes in the Polish board model are divergent. Table 3 contains the results of survey research on the subject. It includes answers of 79 respondents who are the members of the supervisory boards of Polish listed companies. $45.57 \%$ of them i.e. 36 respondents stressed that the existing two-tier board model is suitable for the Polish companies. But $36.71 \%$ i.e. 29 respondents emphasized that the legislature should introduce into the Polish law the possibility of choice by the company (its general meeting) between one-tier and two-tier board model (optional model). Moreover, 6 respondents i.e. $7.59 \%$ underlined that one-tier board model would be better for the Polish companies. Thus, a total of $44.3 \%$ of respondents indicated a need to change the traditional Polish two-tier board model. But until 8 respondents considered that they do not have an opinion on this subject. These results show that in Poland discussion is needed, including research on the pros and cons of both models. In the longer term, this discussion may lead to changes in the Polish board model.

\begin{tabular}{lcc}
\hline Opinion & No. & $\boldsymbol{\%}$ \\
\hline Two-tier board model is suitable for the Polish companies & 36 & 45.57 \\
\hline One-tier board model would be better for the Polish companies & 6 & 7.59 \\
\hline $\begin{array}{l}\text { The legislature should introduce into the Polish law the possibility of choice } \\
\text { by the company (its general meeting) between one-tier and two-tier board } \\
\text { model (optional model) }\end{array}$ & 29 & 36.71 \\
\hline I have no opinion & 8 & 10.13 \\
\hline
\end{tabular}

\section{Conclusions}

The idea of positive organizational potential is derived from psychology and concerns organizational behavior, and its implementation requires, among others, the creation of appropriate conditions for the functioning of an individual in the organization. This study is devoted to the functioning of and potential changes to Polish corporate boards. The introduction of an optional model which would optionally allow the one-tier model (a board of directors) or the two-tier model (a supervisory board and a management board) would improve the utilization of the social and intellectual capital present in the supervisory boards of Polish 
companies. This would allow their members to go beyond oversight functions and get more involved in the development of strategies and policies for the companies. As confirmed by research, this is also the opinion of many members of the supervisory boards. It should be also emphasized that among them, many are supporters of traditional two-tier board model.

Of course, the changes recommended in this paper are only a few of the many that should be considered for Poland and introduced in our country through legislation, or more strongly emphasized in the so-called soft law i.e. best practices in corporate governance. Other relevant solutions involve the presence of legal persons on corporate boards, diversity in the boardroom and the appointment of supervisory board members (in particular, independent members).

\section{References}

Aste, L. (1999), "Reforming French Corporate governance: A Return to the Two-Tier Board?", The George Washington Journal of International Law and Economics, Vol. 32, No. 1, pp. 1-72.

Bohdanowicz, L. (2009), Profesjonalizm w funkcjonowaniu rad nadzorczych spótek akcyjnych, Wydawnictwo UŁ, Łódź.

Cadbury, A. (2002), Corporate Governance and Chairmanship: A Personal View, Oxford University Press, Oxford. DOI:10.1093/acprof:oso/9780199252008.001.0001

Davis, P. (1978), "The Bullock Report and Employee Participation in Corporate Planning in the UK", Journal of Comparative Corporate Law and Securities Regulation", Vol. 1, pp. 245-272.

Demb, A., Neubauer, F.F. (1992), The Corporate Board: Confronting the Paradoxes, Oxford University Press, Oxford.

Garratt, B. (2003), The Fish Rots from the Head - The Crisis in Our Boardrooms: Developing the Crucial Skills of the Competent Director, Profile Books, London.

Haffer, R., Glińska-Neweś, A. (2013), „Pozytywny Potencjał Organizacji jako determinant sukcesu przedsiębiorstwa. Przypadek Polski i Francji”, Zarzqdzanie i Finanse, Vol. 11, No. 4(1), pp. 91-100.

Jeżak, J. (2010), Ład Korporacyjny: Doświadczenia światowe oraz kierunki rozwoju, Wyd. C.H. Beck, Warszawa.

Jungmann C. (2006), "The Effectiveness of Corporate Governance in One-Tier and Two-Tier Board Systems", Company and Financial Law Review, Vol. 3, No. 4, pp. 426-474.

Mayer, C. (1995), „Nadzór nad działalnością spółek w gospodarce rynkowej i w gospodarce okresu transformacji", in: Hessel, M. (Ed.), W poszukiwaniu skutecznej rady, czyli o kontroli spótek akcyjnych $w$ gospodarce rynkowej, Wyd. Profesjonalnej Szkoły Biznesu, Kraków 1995, pp. 27-54.

Millet-Reyes, B., Zhao, R. (2010), "A comparison between one-tier and two-tier board structures in France", Journal of International Financial Management and Accounting, Vol. 21, No. 3, pp. 279-310. DOI:10.1111/j.1467-646X.2010.01042.x

Morck, R., Steier, L. (2005), “The Global History of Corporate Governance: An Introduc- 
DIRECTIONS

$\mathrm{OF}$

CHANGE

Leszek Bohdanowicz tion”, in: Morck, R. (Ed.), A History of Corporate Governance Around the World, The University of Chicago Press, Chicago, pp. 1-64.

Nadler, D.A., Behan, B.A., Nadler, M.B. (2006), Building Better Boards: A blueprint for effective governance, Jossey-Bass, San Francisco.

Pawlak, M. (1996), Działalność rady nadzorczej w spółce akcyjnej na przykładzie doświadczeń niemieckich, Wydawnictwa Uczelniane, Politechnika Lubelska, Lublin.

Rose, C. (2005), "The composition of the semi-two-tier corporate boards and firm performance", Corporate Governance: An International Review, Vol. 13, No. 5, pp. 691-701. DOI:10.1111/j.1467-8683.2005.00460.x

Rozwkitalska, M. (2012), „Interakcje międzykulturowe w ujęciu pozytywnego potencjału organizacji”, Organizacja i Kierowanie, No. 4, pp. 15-28.

Rudolf, S. (2008), „Udział przedstawicieli załogi w radach nadzorczych spółek w nowych krajach Unii Europejskiej", in: Rudolf, S. (Ed.), Rola nadzoru korporacyjnego w kreowaniu wartości przedsiębiorstwa, Wyd. Uniwersytetu Łódzkiego, Łódź, pp. 393-408.

Rudolf, S., Janusz, T., Stos, D., Urbanek, P. (2002), Efektywny nadzór korporacyjny, PWE, Warszawa.

Siemiątkowski, T. (2004), „System monistyczny ładu korporacyjnego - krok ku przyszłości”, Nasz Rynek Kapitałowy, No. 11, pp. 53-55.

Spisto, M. (2005), "Unitary Board and Two-tiered Board for the New South Africa?", International Review of Business Research Papers, Vol. 1, No. 2, pp. 84-99.

Stankiewicz, M.J. (Ed.) (2010), Pozytywny potencjat organizacji. Wstęp do użytecznej teorii zarządzania, Dom Organizatora, Toruń.

The European Commission (2009), Study on Monitoring and Enforcement Practices in Corporate Governance in the Member States, 23 September.

Tricker, B. (2009), Corporate Governance: Principles, Policies, and Practices, Oxford University Press, Oxford.

Van Bekkum, J., Hijink, J., Schouten, M., Winter, J. (2010), “Corporate Governance in the Netherlands", Electronic Journal of Comparative Law, Vol. 14, No. 3, available at: http://www.ejcl.org/143/art143-17.pdf, (accessed 15 May 2013). 